\title{
Clinical and Serologic Markers of Periodontal Infection and Chronic Kidney Disease
}

\author{
Monica A. Fisher, ${ }^{*}$ George W. Taylor, ${ }^{\dagger}$ Panos N. Papapanou, ${ }^{\ddagger}$ Mahboob Rahman, $\S$
} and Sara M. Debannell

Background: Chronic kidney disease and its concomitant sequelae represent a major public health problem. Recent data suggest periodontal infection contributes to chronic kidney disease.

Methods: This United States population-based study of 4,053 adults $\geq 40$ years of age investigated the association between chronic kidney disease and clinical measures and serologic markers of periodontal infection. Chronic kidney disease was defined as moderateto-severe reduction of kidney function with glomerular filtration rate of 15 to $59 \mathrm{ml} /$ minute $/ 1.73 \mathrm{~m}^{2}$ based on stages 3 and 4 of the Kidney Disease Outcome Quality Initiative. Chronic oral inflammatory burden was measured as 1) clinical periodontal infection categorized as no periodontal disease, periodontal disease (at least one tooth with $\geq 4 \mathrm{~mm}$ loss of attachment and bleeding on probing as an indicator of inflammation), or edentulism and 2) serum immunoglobulin $G$ antibody response to Aggregatibacter actinomycetemcomitans (previously Actinobacillus actinomycetemcomitans) and Porphyromonas gingivalis. Multiple logistic regression modeling quantified the association between chronic kidney disease and chronic inflammatory burden and other risk factors.

Results: Nine percent of the study population had chronic kidney disease, $22 \%$ had high $A$. actinomycetemcomitans antibody titer, $24 \%$ had high $P$. gingivalis antibody titer, $9 \%$ had periodontal disease, and $17 \%$ were edentulous. After simultaneously adjusting for recognized risk factors, adults with a high $A$. actinomycetemcomitans titer were less likely to have chronic kidney disease (adjusted odds ratio $\left[\mathrm{OR}_{\text {Adj }}\right]=0.67 ; 95 \%$ confidence interval $[\mathrm{CI}]: 0.46$ to 0.98 ), and adults with edentulism were more likely to have chronic kidney disease $\left(\mathrm{OR}_{\mathrm{Adj}}=1.64 ; 95 \% \mathrm{CI}: 1.11\right.$ to 2.44$)$.

Conclusion: These results support considering edentulism and low serum titer to $A$. actinomycetemcomitans as risk indicators for chronic kidney disease. J Periodontol 2008;79:1670-1678.

\section{KEY WORDS}

Antibodies; jaws, edentulous; kidney diseases; periodontal diseases; risk factors.

\footnotetext{
* Department of Orthodontics, School of Dental Medicine, Case Western Reserve University, Cleveland, $\mathrm{OH}$.

$\dagger$ Department of Cariology, Restorative Sciences, and Endodontics, School of Dentistry, University of Michigan, Ann Arbor, MI.

‡ Section of Oral and Diagnostic Sciences, Division of Periodontics, College of Dental Medicine, Columbia University, New York, NY.

$\S$ Division of Nephrology and Hypertension, School of Medicine, Case Western Reserve University.

II Department of Epidemiology and Biostatistics, School of Medicine, Case Western Reserve University.
}

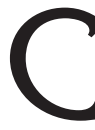
hronic kidney disease and its concomitant serious sequelae (i.e., end-stage kidney failure, cardiovascular disease, and premature death) represent a major public health problem in the United States. ${ }^{1}$ During 1999 to 2000, an estimated 7 million adults in the United States had chronic kidney disease on the basis of a moderateto-severe reduction of kidney function (glomerular filtration rate [GFR] between 15 and $59 \mathrm{ml} /$ minute/1.73 $\left.\mathrm{m}^{2}\right) .^{2}$ This level of decreased kidney function corresponds to stages 3 and 4 of the Kidney Disease Outcome Quality Initiative. ${ }^{3}$

Chronic inflammatory burden has been suggested as a risk factor for chronic kidney disease ${ }^{4-7}$ and atherosclerotic cardiovascular disease. ${ }^{5}$ Recent data suggest that high periodontal pathogen antibody titers, ${ }^{8}$ periodontal disease incorporating bleeding as an indicator of active inflammation, ${ }^{9}$ and markers of chronic inflammatory burden contribute to chronic kidney disease. ${ }^{6}$ Systemic dissemination of bacterial pathogens, antigens, endotoxins, and inflammatory cytokines is related to the chronic inflammatory burden of periodontal disease. ${ }^{10,11}$

As a source of systemic inflammatory burden, it is biologically plausible to consider periodontal

doi: 10.1902/jop.2008.070569 
disease as a putative risk factor for chronic kidney disease. In a recent report ${ }^{12}$ from a nationally representative population sample, high antibody titers to the periodontal pathogen Porphyromonas gingivalis and clinical periodontal disease were independently associated with high levels of the inflammatory marker C-reactive protein but high antibody titers to Aggregatibacter actinomycetemcomitans (previously Actinobacillus actinomycetemcomitans) were not.

The purpose of this study was to evaluate and quantify the independent association between clinical and serologic markers of periodontal infection and chronic kidney disease in a representative sample of the United States population. We also considered C-reactive protein as an additional factor that may contribute to the chronic inflammatory burden.

\section{MATERIALS AND METHODS}

\section{Study Population}

This cross-sectional study was approved by the Case Western Reserve University institutional review board. The Third National Health and Nutrition Examination Survey (NHANES III), conducted between 1988 and 1994, is a complex, multistage, stratified, clustered sample representative of the civilian, non-institutionalized United States population. NHANES III included questionnaire, laboratory assays, and clinical examination measures of health outcomes and explanatory variables. ${ }^{13}$ We identified 4,053 adults $\geq 40$ years of age with a mean age of 57.4 years, representing 42.5 million Americans, with information on kidney function and assessments of serum immunoglobulin $G$ antibody against $A$. actinomycetemcomitans and $P$. gingivalis. Similar to a previous analysis of this dataset, ${ }^{12}$ we excluded those among the upper and lower $2 \%$ of reported antibody titers to minimize the effects of extreme values.

\section{Description of Main Outcome}

The main outcome was chronic kidney disease with moderate-to-severe reduction of kidney function defined by a GFR 15 to $59 \mathrm{ml} /$ minute $/ 1.73 \mathrm{~m}^{2}$ based on stages 3 and 4 of the Kidney Disease Outcome Quality Initiative. ${ }^{3}$ The combination of moderately and severely decreased kidney function provides a single, more precise estimate of decreased kidney function. ${ }^{2}$ GFR was estimated using the simplified Modification of Diet in Renal Disease Study equation: GFR $=186.3 \times(\text { serum creatinine in } \mathrm{mg} / \mathrm{dl})^{-1.154} \times$ age $^{-0.203} \times(0.742$ if female $) \times(1.21$ if black $)$. The serum creatinine value was calibrated by subtracting 0.23 to align the NHANES measures with creatinine assays in the aforementioned equation. ${ }^{14}$

\section{Description of Risk Factors and Risk Indicators}

The main exposure or risk indicator for this analysis was chronic oral inflammatory burden measured as dentate status and clinical and serologic markers of periodontal infection. Clinical periodontal infection was defined using three categories: no periodontal disease, periodontal disease, or edentulous status. Periodontal disease was defined as having one or more teeth with loss of attachment $\geq 4 \mathrm{~mm}$ and bleeding on probing (with bleeding on probing as an indicator of active inflammation). ${ }^{15}$ Edentulous was defined as having lost all natural teeth. The rationale for including edentulism in the analysis was based on the observation that periodontal disease is the major cause of edentulism among 40- to 69-year-olds, with $60.5 \%$ of teeth extracted due to periodontal disease; ${ }^{16}$ tooth loss was a marker of past periodontal disease among adults $\geq 55$ years of age; ${ }^{17}$ and non-surgical periodontal therapy was associated with a reduction in the rate of tooth loss. ${ }^{18}$

Serologic markers of periodontal infection were measured as periodontal pathogen antibody levels, categorized with the upper $20 \%$ titer levels identifying high titers and the lower $80 \%$ titers identifying low titers. The following four combinations of $A$. actinomycetemcomitans and $P$. gingivalis antibody titers were used: high $A$. actinomycetemcomitans and high $P$. gingivalis titer, high $A$. actinomycetemcomitans and low $P$. gingivalis titer, low A. actinomycetemcomitans and high $P$. gingivalis titer, and low A. actinomycetemcomitans and high $P$. gingivalis titer. The detection of antibodies to A. actinomycetemcomitans and $P$. gingivalis was carried out by enzyme-linked immunosorbent assay as described in the NHANES III Periodontal Pathogen Antibody Documentation. ${ }^{13}$

Other recognized risk factors for chronic kidney disease included age (40- to 59-year-olds versus $\geq 60$-year-olds), race/ethnicity (non-Hispanic white, non-Hispanic black, and Mexican-Americans), lower income ( $<\$ 20,000$ annual household income), education (high school graduate), and systemic hypertension (systolic pressure $>140 \mathrm{~mm} \mathrm{Hg}$ or diastolic pressure $>90 \mathrm{~mm} \mathrm{Hg}$, or being told on two or more different visits that one had hypertension). Blood pressure was measured according to the standardized procedures recommended by the American Heart Association $^{19}$ to reduce misclassification bias. Other risk factors included self-reported smoking status (current, former, or never-smoker), macroalbuminuria (urinary albumin-to-creatinine excretion ratio $\geq 300$ $\mathrm{mg} / \mathrm{g}$ ), 2,3 high C-reactive protein (as a marker for systemic inflammatory burden, $>3.0 \mathrm{mg} / \mathrm{dl}$ ), high total serum cholesterol $(\geq 240 \mathrm{mg} / \mathrm{dl})$, low serum highdensity lipoprotein cholesterol $(\leq 35 \mathrm{mg} / \mathrm{dl})$, high serum low-density lipoprotein cholesterol $(\geq 160 \mathrm{mg} /$ $\mathrm{dl}$ ), obesity (body mass index $\geq 30 \mathrm{~kg} / \mathrm{m}^{2}$ ), and diabetes mellitus status (no diabetes, diabetes with good control $[<7 \%$ glycated hemoglobin], and diabetes with poorer control [ $\geq 7 \%$ glycated hemoglobin]). 
Diabetes mellitus was defined as fasting plasma glucose $\geq 126 \mathrm{mg} / \mathrm{dl}$ or $\geq 200 \mathrm{mg} / \mathrm{dl}$ after an oral glucose tolerance test, ${ }^{20}$ or self-reported, physiciandiagnosed diabetes.

\section{Statistical Analyses}

Tests of the hypotheses that clinical and serologic markers of periodontal infection and other risk factors were associated with chronic kidney disease were examined using univariable analysis and multivariable logistic regression modeling. For the latter, a forward stepwise regression approach was performed to simultaneously take into account the statistically significant risk factors determined by univariable analyses, with statistical significance reported as 95\% confidence interval (CI) not including the value of 1.0 . The independent association was quantified using the adjusted odds ratio $\left(\mathrm{OR}_{\mathrm{Adj}}\right)$ for the association between chronic kidney disease and the following risk factors/risk markers: measures of socioeconomic status (i.e., age, race/ethnicity, gender, income, and education), health status, health behavior, biomarkers, and health care use. Analyses were conducted using software packages ${ }^{\text {I\# }}$ to account for complex survey design and sample weights and to produce national estimates.

\section{RESULTS}

\section{Overall Descriptive Summary}

Table 1 presents important characteristics of the study population and their unadjusted association with chronic kidney disease. The prevalence of chronic kidney disease was 9\% in this United States population-based study. The following health conditions were common and were associated with chronic kidney disease in univariable analyses: $17 \%$ were edentulous $\left(\mathrm{OR}_{\text {Crude }}=3.54\right.$; 95\% CI: 2.54 to 4.93$)$, $11 \%$ had diabetes mellitus with better glycemic control $\left(\mathrm{OR}_{\text {Crude }}=1.58 ; 95 \% \mathrm{CI}: 1.08\right.$ to 2.30$), 7 \%$ had diabetes mellitus with poorer glycemic control $\left(\mathrm{OR}_{\text {Crude }}=\right.$ 1.89; $95 \%$ CI: 1.20 to 2.98$), 41 \%$ had hypertension $\left(\mathrm{OR}_{\text {Crude }}=4.29 ; 95 \% \mathrm{CI}: 3.17\right.$ to 5.81$), 26 \%$ had high cholesterol $\left(\mathrm{OR}_{\text {Crude }}=1.82 ; 95 \% \mathrm{CI}: 1.35\right.$ to 2.47$), 15 \%$ had low high-density lipoprotein $\left(\mathrm{OR}_{\text {Crude }}=1.67 ; 95 \%\right.$ CI: 1.07 to 2.60 ), and $21 \%$ had high low-density lipoprotein $\left(\mathrm{OR}_{\text {Crude }}=1.61 ; 95 \% \mathrm{CI}: 1.05\right.$ to 2.47$)$. In addition, $9 \%$ had periodontal disease $\left(\mathrm{OR}_{\text {Crude }}=1.26\right.$; $95 \%$ CI: 0.78 to 2.03$)$ and $29 \%$ were obese $\left(\mathrm{OR}_{\text {Crude }}=\right.$ 1.08; $95 \%$ CI: 0.73 to 1.59); neither of these was significantly associated with chronic kidney disease in univariable analysis. The following health conditions were less common and were associated with chronic kidney disease in univariable analysis: $2 \%$ had macroalbuminuria $\left(\mathrm{OR}_{\text {Crude }}=8.47 ; 95 \% \mathrm{CI}: 5.13\right.$ to 14.00$)$, and $1 \%$ had high $C$-reactive protein $\left(\mathrm{OR}_{\text {Crude }}=2.60\right.$; 95\% CI: 1.11 to 6.07$)$.

\section{Multivariable Logistic Regression Models}

Table 2 presents the most parsimonious models of clinical and serologic markers of periodontal infection and other risk factors for chronic kidney disease, simultaneously adjusting for the listed risk factors. The first model with clinical periodontal infection (column 2$)$ indicates adults who were edentulous $\left(\mathrm{OR}_{\mathrm{Adj}}=\right.$ $1.61 ; 95 \%$ CI: 1.09 to 2.37$)$, older $\left(\mathrm{OR}_{\mathrm{Adj}}=8.60 ; 95 \%\right.$ CI: 5.15 to 14.35$)$, non-Hispanic white $\left(\mathrm{OR}_{\mathrm{Adj}}=2.68\right.$; $95 \% \mathrm{CI}: 1.40$ to 5.14$)$, female $\left(\mathrm{OR}_{\mathrm{Adj}}=1.91 ; 95 \% \mathrm{CI}\right.$ : 1.20 to 3.04$)$, had an annual physician visit $\left(\mathrm{OR}_{\mathrm{Adj}}=\right.$ 2.32; 95\% CI: 1.12 to 4.79$)$, had low high-density lipoprotein $\left(\mathrm{OR}_{\mathrm{Adj}}=2.04 ; 95 \% \mathrm{CI}: 1.22\right.$ to 3.41$)$, had hypertension $\left(\mathrm{OR}_{\mathrm{Adj}}=1.86 ; 95 \% \mathrm{CI}\right.$ : 1.35 to 2.56$)$, did not graduate from high school $\left(\mathrm{OR}_{\mathrm{Adj}}=1.37 ; 95 \%\right.$ CI: 1.06 to 1.76$)$, were former smokers $\left(\mathrm{OR}_{\mathrm{Adj}}=\right.$ 1.38 ; $95 \% \mathrm{Cl}: 1.05$ to 1.81 ), or who had macroalbuminuria $\left(\mathrm{OR}_{\mathrm{Adj}}=4.07 ; 95 \% \mathrm{CI}\right.$ : 2.51 to 6.59$)$ were more likely to have chronic kidney disease, after simultaneously adjusting for these factors.

In the next model (Table 2, column 3) containing clinical periodontal infection and $A$. actinomycetemcomitans antibody titer, edentulous adults remained more likely to have chronic kidney disease $\left(\mathrm{OR}_{\mathrm{Adj}}=\right.$ 1.58; $95 \% \mathrm{CI}: 1.07$ to 2.34 ), and adults with high A. actinomycetemcomitans antibody titer were less likely to have chronic kidney disease $\left(\mathrm{OR}_{\mathrm{Adj}}=0.67\right.$; $95 \%$ CI: 0.46 to 0.98 ). In the last model (Table 2, column 4) containing the combination of A. actinomycetemcomitans and $P$. gingivalis antibody titers and clinical periodontal infection status, adults with high A. actinomycetemcomitans titer and low $P$. gingivalis titer were less likely to have chronic kidney disease $\left(\mathrm{OR}_{\text {Adj }}=0.61 ; 95 \% \mathrm{Cl}: 0.39\right.$ to 0.97$)$ than those with low $A$. actinomycetemcomitans titer and low $P$. gingivalis titer, after simultaneously adjusting for other factors.

In all three models, there was little change in the estimated adjusted OR for the nine other factors independently associated with chronic kidney disease: age, race/ethnicity, gender, smoking status, macroalbuminuria, high-density lipoprotein, hypertension, education, and health care use (i.e., annual physician visit). The following risk factors were not included in the final models because they were not statistically significant: lower income, diabetes status, obesity, high C-reactive protein, low-density lipoprotein cholesterol, and being hospitalized in the past year.

\section{DISCUSSION}

We investigated the independent association between prevalent chronic kidney disease and chronic oral and systemic inflammatory burden measured as 1) clinical periodontal infection incorporating the current

\footnotetext{
I SAS-Callable SUDAAN version 9.0.1, Research Triangle Institute, Research Triangle Park, NC.
}

\# SAS Systems for Windows, version 9.1, SAS Institute, Cary, NC. 
Table I.

Descriptive Summary and Associations Between Risk Factors and Chronic Kidney Disease in United States Adults $\geq 40$ Years of Age

\begin{tabular}{|c|c|c|c|}
\hline Risk Factors* & $\begin{array}{l}\text { No Chronic Kidney Disease } \\
\qquad(n=3,632 ; 91.5 \%)\end{array}$ & $\begin{array}{l}\text { Chronic Kidney Disease } \\
\qquad(n=421 ; 8.5 \%)\end{array}$ & OR Crude $(95 \% \mathrm{Cl})$ \\
\hline \multicolumn{4}{|l|}{ Socioeconomic } \\
\hline $\begin{array}{l}\text { Age (years) } \\
40 \text { to } 59(n=1,866 ; 59.1 \%) \\
\geq 60(n=2,187 ; 40.9 \%)\end{array}$ & $\begin{array}{l}98.2 \% \\
81.8 \%\end{array}$ & $\begin{array}{r}1.8 \% \\
18.2 \%\end{array}$ & $\begin{array}{l}1.00 \\
12.05(7.17 \text { to } 20.27)^{\dagger}\end{array}$ \\
\hline $\begin{array}{l}\text { Gender } \\
\text { Female ( } n=2,246 ; 54.2 \%) \\
\text { Male }(n=1,807 ; 45.8 \%)\end{array}$ & $\begin{array}{l}90.2 \% \\
93.0 \%\end{array}$ & $\begin{array}{l}9.8 \% \\
7.0 \%\end{array}$ & $\begin{array}{l}1.45(1.01 \text { to } 2.09)^{\dagger} \\
1.00\end{array}$ \\
\hline $\begin{array}{l}\text { High school graduate } \\
\text { Yes }(n=2,238 ; 73.2 \%) \\
\text { No }(n=1,786 ; 26.8 \%)\end{array}$ & $\begin{array}{l}93.6 \% \\
85.6 \%\end{array}$ & $\begin{array}{r}6.4 \% \\
14.4 \%\end{array}$ & $\begin{array}{l}1.00 \\
2.48(1.89 \text { to } 3.25)^{\dagger}\end{array}$ \\
\hline Health status and health behavior & & & \\
\hline $\begin{array}{l}\text { Periodontal antibodies } \\
\text { Aa } \\
\text { High } A a(n=1,084 ; 22.0 \%) \\
\text { Low } A a(n=2,969 ; 78.0 \%) \\
\text { Pg } \\
\text { High Pg }(n=1,375 ; 24.4 \%) \\
\text { Low Pg }(n=2,678 ; 75.6 \%) \\
\text { Combination of Aa and Pg } \\
\text { High } A a \text { and high Pg }(n=533 ; 8.1 \%) \\
\text { High } A a \text { and low Pg }(n=551 ; 13.9 \%) \\
\text { Low } A a \text { and high Pg }(n=842 ; 16.3 \%) \\
\text { Low } A a \text { and low Pg }(n=2,127 ; 61.7 \%)\end{array}$ & $\begin{array}{l}91.5 \% \\
91.4 \% \\
93.2 \% \\
94.5 \% \\
90.7 \% \\
90.7 \%\end{array}$ & $\begin{array}{l}8.5 \% \\
8.6 \% \\
\\
6.8 \% \\
5.5 \% \\
9.3 \% \\
9.3 \%\end{array}$ & $\begin{array}{l}0.99(0.68 \text { to } 1.43) \\
1.00 \\
0.72(0.43 \text { to } 1.21) \\
0.58(0.34 \text { to } 0.97)^{\dagger} \\
1.00(0.64 \text { to } 1.57) \\
1.00\end{array}$ \\
\hline $\begin{array}{l}\text { Periodontal status } \\
\text { Edentulous }(n=803 ; 17.1 \%) \\
\text { Periodontal disease }(n=526 ; 8.5 \%) \\
\text { No periodontal disease }(n=2,724 ; 74.4 \%)\end{array}$ & $\begin{array}{l}81.0 \% \\
92.3 \% \\
93.8 \%\end{array}$ & $\begin{array}{r}19.0 \% \\
7.7 \% \\
6.2 \%\end{array}$ & $\begin{array}{l}3.54(2.54 \text { to } 4.93)^{\dagger} \\
1.26(0.78 \text { to } 2.03) \\
1.00\end{array}$ \\
\hline $\begin{array}{l}\text { Diabetes status } \\
\text { Poor control }(n=396 ; 6.8 \%) \\
\text { Good control }(n=520 ; 10.9 \%) \\
\text { No diabetes }(n=3,137 ; 82.3 \%)\end{array}$ & $\begin{array}{l}86.4 \% \\
88.4 \% \\
92.3 \%\end{array}$ & $\begin{array}{r}13.6 \% \\
11.6 \% \\
7.7 \%\end{array}$ & $\begin{array}{l}1.89(1.20 \text { to } 2.98)^{\dagger} \\
1.58(1.08 \text { to } 2.30)^{\dagger} \\
1.00\end{array}$ \\
\hline $\begin{array}{l}\text { Hypertension } \\
\text { Yes }(n=2,003 ; 40.6 \%) \\
\text { No }(n=2,047 ; 59.4 \%)\end{array}$ & $\begin{array}{l}84.8 \% \\
96.0 \%\end{array}$ & $\begin{array}{r}15.2 \% \\
4.0 \%\end{array}$ & $\begin{array}{l}4.29(3.17 \text { to } 5.81)^{\dagger} \\
1.00\end{array}$ \\
\hline $\begin{array}{l}\text { Macroalbuminuria } \\
\qquad \begin{array}{l}\text { Yes }(n=141 ; 1.7 \%) \\
\text { No }(n=3,912 ; 98.3 \%)\end{array}\end{array}$ & $\begin{array}{l}57.7 \% \\
92.0 \%\end{array}$ & $\begin{array}{r}42.3 \% \\
8.0 \%\end{array}$ & $\begin{array}{l}8.47(5.13 \text { to } 14.00)^{\dagger} \\
1.00\end{array}$ \\
\hline
\end{tabular}


Table I. (continued)

\section{Descriptive Summary and Associations Between Risk Factors and Chronic Kidney Disease in United States Adults $\geq 40$ Years of Age}

\begin{tabular}{|c|c|c|c|}
\hline Risk Factors* & $\begin{array}{l}\text { No Chronic Kidney Disease } \\
\quad(n=3,632 ; 91.5 \%)\end{array}$ & $\begin{array}{l}\text { Chronic Kidney Disease } \\
\qquad(n=421 ; 8.5 \%)\end{array}$ & OR Crude $(95 \% \mathrm{Cl})$ \\
\hline \multicolumn{4}{|l|}{ Obesity } \\
\hline Yes $(n=1,220 ; 28.8 \%)$ & $91.0 \%$ & $9.0 \%$ & \multirow{2}{*}{$\begin{array}{l}1.08(0.73 \text { to } 1.59) \\
1.00\end{array}$} \\
\hline No $(n=2,827 ; 71.2 \%)$ & $91.6 \%$ & $8.4 \%$ & \\
\hline \multicolumn{4}{|l|}{ High C-reactive protein } \\
\hline Yes $(n=78 ; 1.3 \%)$ & $80.8 \%$ & $19.2 \%$ & \multirow{2}{*}{$\begin{array}{l}2.60(1.11 \text { to } 6.07)^{\dagger} \\
1.00\end{array}$} \\
\hline No $(n=3,973 ; 98.7 \%)$ & $91.6 \%$ & $8.4 \%$ & \\
\hline \multicolumn{4}{|l|}{ High cholesterol } \\
\hline Yes $(n=1,095 ; 26.3 \%)$ & $87.6 \%$ & $12.4 \%$ & \multirow{2}{*}{$\begin{array}{l}1.82(1.35 \text { to } 2.47)^{\dagger} \\
1.00\end{array}$} \\
\hline No $(n=2,943 ; 73.7 \%)$ & $92.8 \%$ & $7.2 \%$ & \\
\hline \multicolumn{4}{|l|}{ Low high-density lipoprotein } \\
\hline Yes $(n=579 ; 14.7 \%)$ & $87.5 \%$ & $12.5 \%$ & \multirow{2}{*}{$\begin{array}{l}1.67(1.07 \text { to } 2.60)^{\dagger} \\
1.00\end{array}$} \\
\hline No $(n=3,423 ; 85.3 \%)$ & $92.1 \%$ & $7.9 \%$ & \\
\hline \multicolumn{4}{|l|}{ High low-density lipoprotein } \\
\hline Yes $(n=392,20.9 \%)$ & $89.3 \%$ & $10.7 \%$ & \multirow{2}{*}{$\begin{array}{l}1.61(1.05 \text { to } 2.47)^{\dagger} \\
1.00\end{array}$} \\
\hline No $(n=1,322,79.1 \%)$ & $93.0 \%$ & $7.0 \%$ & \\
\hline \multicolumn{4}{|l|}{ Smoking status } \\
\hline Never $(n=1,899 ; 44.0 \%)$ & $91.6 \%$ & $8.4 \%$ & \multirow{3}{*}{$\begin{array}{l}1.92(1.21 \text { to } 3.05)^{t} \\
2.64(1.64 \text { to } 4.25)^{t} \\
1.00\end{array}$} \\
\hline Former $(n=1,265 ; 33.9 \%)$ & $88.8 \%$ & $11.2 \%$ & \\
\hline Current $(n=889 ; 22.1 \%)$ & $95.4 \%$ & $4.6 \%$ & \\
\hline \multicolumn{4}{|l|}{ Hospitalized in past year } \\
\hline Yes $(n=662 ; 13.6 \%)$ & $86.4 \%$ & $13.6 \%$ & \multirow{2}{*}{$\begin{array}{l}1.89(1.33 \text { to } 2.70)^{\dagger} \\
1.00\end{array}$} \\
\hline No $(n=3,378 ; 86.4 \%)$ & $92.3 \%$ & $7.7 \%$ & \\
\hline \multicolumn{4}{|l|}{ Annual physician visit } \\
\hline Yes $(n=3,393 ; 82.9 \%)$ & $90.6 \%$ & $9.4 \%$ & \multirow{2}{*}{$\begin{array}{l}3.02(1.50 \text { to } 6.08)^{\dagger} \\
1.00\end{array}$} \\
\hline No $(n=636 ; 17.1 \%)$ & $96.7 \%$ & $3.3 \%$ & \\
\hline
\end{tabular}

Unweighted number with weighted percent.

Inclusion criteria: periodontal pathogen titers and serum creatinine data.

$\mathrm{OR}_{\text {Crude }}=$ unadjusted OR for the association between chronic kidney disease and the listed risk factors; Aa = A. actinomycetemcomitans; Pg = P. gingivalis

* Not all participants answered all questions or had all serum assays performed.

$\dagger P<0.05$.

presence of periodontal inflammation in the clinical measure by requiring bleeding on probing on the same tooth with attachment loss; ${ }^{15}$ 2) systemic antibody response to periodontal pathogens; $8,10-12,21-28$ and 3) C-reactive protein. ${ }^{4,6,12}$ Edentulism and specific serologic markers of periodontal infection were independent risk indicators for chronic kidney disease. High C-reactive protein was not found to be an independent risk factor after simultaneously considering several other recognized risk markers for chronic kidney disease, i.e., age, race/ethnicity, gender, education, smoking status, annual physician visit, high-density lipoprotein, hypertension, and macroalbuminuria.

Our study approach contributes to previous evidence by supporting the concept of the role of chronic inflammatory burden in chronic kidney disease path- ogenesis through the assessment of the systemic antibody response to periodontal pathogens and by including edentulous adults who represented $17 \%$ of the United States population $\geq 40$ years of age. Our population-based study is consistent with previous studies ${ }^{1-3,9,29-32}$ of high-risk chronic kidney disease subgroups and provides a basis to consider extending the list of risk factors/indicators to include clinical and serologic markers of periodontal infection in a multivariable model of risk for chronic kidney disease.

Based on the current evidence that chronic infection by dental plaque bacteria is etiologic for periodontal disease, it is biologically plausible to hypothesize that the systemic inflammatory burden related to periodontal disease is associated with chronic kidney disease. The response to periodontal pathogens leads to a local, 
Table 2.

Final Logistic Regression Models of Association Between Clinical and Serologic Markers of Periodontal Infection and Chronic Kidney Disease in United States Adults $\geq 40$ Years of Age

\begin{tabular}{|c|c|c|c|}
\hline Risk Factor & $\begin{array}{l}\text { Model With Clinical } \\
\text { Periodontal Infection } \\
\text { OR }_{\text {Adj }}(95 \% \mathrm{Cl})\end{array}$ & $\begin{array}{l}\text { Model With Clinical Periodontal } \\
\text { Infection and Aa Antibody Titer } \\
\qquad \mathrm{OR}_{\text {Adj }}(95 \% \mathrm{Cl})\end{array}$ & $\begin{array}{l}\text { Model With Clinical Periodontal } \\
\text { Infection, Aa and Pg Antibody Titers } \\
\qquad \mathrm{OR}_{\text {Adj }}(95 \% \mathrm{Cl})\end{array}$ \\
\hline $\begin{array}{l}\text { Periodontal clinical status } \\
\text { Edentulous } \\
\text { Periodontal disease } \\
\text { No periodontal disease }\end{array}$ & $\begin{array}{l}1.61(1.09 \text { to } 2.37)^{*} \\
1.20(0.76 \text { to } 1.90) \\
1.00\end{array}$ & $\begin{array}{l}1.58(1.07 \text { to } 2.34)^{*} \\
1.23(0.78 \text { to } 1.95) \\
1.00\end{array}$ & $\begin{array}{l}1.64(1.11 \text { to } 2.44)^{*} \\
1.20(0.75 \text { to } 1.93) \\
1.00\end{array}$ \\
\hline $\begin{array}{l}\text { Race/ethnicity } \\
\text { Non-Hispanic white } \\
\text { Non-Hispanic black } \\
\text { Mexican American }\end{array}$ & $\begin{array}{l}2.68(1.40 \text { to } 5.14)^{*} \\
1.53(0.73 \text { to } 3.18) \\
1.00\end{array}$ & $\begin{array}{l}2.57(1.34 \text { to } 4.91)^{*} \\
1.48(0.71 \text { to } 3.09) \\
1.00\end{array}$ & $\begin{array}{l}2.70(1.39 \text { to } 5.27)^{*} \\
1.47(0.70 \text { to } 3.08) \\
1.00\end{array}$ \\
\hline $\begin{array}{l}\text { Gender } \\
\text { Female } \\
\text { Male }\end{array}$ & $\begin{array}{l}1.91(1.20 \text { to } 3.04)^{*} \\
1.00\end{array}$ & $\begin{array}{l}1.86(1.17 \text { to } 2.97)^{*} \\
1.00\end{array}$ & $\begin{array}{l}1.86(1.17 \text { to } 2.95)^{*} \\
1.00\end{array}$ \\
\hline $\begin{array}{l}\text { Annual physician visit } \\
\text { Yes } \\
\text { No }\end{array}$ & $\begin{array}{l}2.32(1.12 \text { to } 4.79)^{*} \\
1.00\end{array}$ & $\begin{array}{l}2.33(1.13 \text { to } 4.82)^{*} \\
1.00\end{array}$ & $\begin{array}{l}2.40(1.18 \text { to } 4.86)^{*} \\
1.00\end{array}$ \\
\hline $\begin{array}{l}\text { Low high-density lipoprote } \\
\text { Yes } \\
\text { No }\end{array}$ & $\begin{array}{l}2.04(1.22 \text { to } 3.41)^{*} \\
1.00\end{array}$ & $\begin{array}{l}2.01 \\
1.00\end{array}(1.20 \text { to } 3.38)^{*}$ & $\begin{array}{l}2.00(1.19 \text { to } 3.37)^{*} \\
1.00\end{array}$ \\
\hline $\begin{array}{l}\text { Hypertension } \\
\text { Yes } \\
\text { No }\end{array}$ & $\begin{array}{l}1.86(1.35 \text { to } 2.56)^{*} \\
1.00\end{array}$ & $\begin{array}{l}1.87(1.36 \text { to } 2.56)^{*} \\
1.00\end{array}$ & $\begin{array}{l}1.86(1.36 \text { to } 2.55)^{*} \\
1.00\end{array}$ \\
\hline $\begin{array}{l}\text { Macroalbuminuria } \\
\text { Yes } \\
\text { No }\end{array}$ & $\begin{array}{l}4.07(2.51 \text { to } 6.59)^{*} \\
1.00\end{array}$ & $\begin{array}{l}4.02(2.42 \text { to } 6.69)^{*} \\
1.00\end{array}$ & $\begin{array}{l}4.03(2.40 \text { to } 6.74)^{*} \\
1.00\end{array}$ \\
\hline
\end{tabular}

$\mathrm{OR}_{\mathrm{Adj}}=\mathrm{OR}$ for the association between chronic kidney disease, simultaneously taking into account all of the risk factors included in the model; Aa = A. actinomycetemcomitans; $P g=P$. gingivalis.

The following risk factors were not included in the final model because they were not statistically significant: lower income, diabetes status, obesity, high $C$-reactive protein, low-density lipoprotein cholesterol, and hospitalized in the past year.

$* P<0.05$. 
tissue-destructive immunoinflammatory response that is believed to create a chronic systemic inflammatory burden secondary to the systemic dissemination of periodontal pathogenic bacteria, their products (e.g., lipopolysaccharides), and locally produced inflammatory mediators including cytokines, chemokines, and inflammatory peptides. ${ }^{25,26}$ This systemic inflammatory burden has been suggested to contribute to endothelial injury and atherogenesis. ${ }^{22,33}$ An increasing body of epidemiologic evidence supports a significant association between periodontal infections (i.e., systemic antibody titers to periodontal pathogens) and cardiovascular diseases. ${ }^{21,24,27}$ Additionally, clinical studies involving treatment of chronic periodontitis reported an improvement of secondary endpoints considered important in cardiovascular disease risk, ${ }^{26}$ including a recently reported randomized clinical trial ${ }^{22}$ demonstrating a significant improvement in endothelial function following periodontal treatment.

In our study of a representative sample of the United States population, clinical periodontal status and serologic markers of periodontal infection were independently associated with chronic kidney disease. First, we modeled the association between chronic kidney disease and clinical periodontal infection and found a significant association with dentate status (i.e., edentulism) but not with periodontal disease (this may be an underestimate of the true association; see later discussion). After adding serologic markers of periodontal infection to the model, A. actinomycetemcomitans titer remained significantly associated with chronic kidney disease when the combination of $A$. actinomycetemcomitans and $P$. gingivalis titers was evaluated, suggesting that a composite systemic antibody response to the total periodontal pathogen burden may be important in this context. In our analysis, individuals with a combination of high $A$. actinomycetemcomitans titer and low $P$. gingivalis titer remained significantly less likely to have chronic kidney disease than those with low A. actinomycetemcomitans titer and low $P$. gingivalis titer. Our finding is somewhat contrary to the recent report ${ }^{8}$ from the Atherosclerosis Risk in Communities (ARIC) study that reported high antibody titers to $P$. gingivalis were associated with chronic kidney disease.

A limitation of the dental component of the ARIC study and our study is the cross-sectional study design, which precludes assessment of the temporal association between the systemic antibody response to periodontal pathogens and chronic kidney disease. In addition, it is not feasible to determine whether high levels of antibody titers to periodontal pathogens signify a new occurrence of infection or a current chronic or previously resolved bacterial infection. An earlier study $^{28}$ suggested systemic antibody titers might reflect a history of periodontal infection. This may explain the association between edentulism and chronic kidney disease; if some of the teeth of edentulous adults had long-term periodontal disease (all of the teeth need not have been extracted as a result of periodontal disease), the resultant chronic inflammatory burden may have played a role in the kidney damage.

Another limitation of our study is the probable underestimation of clinical periodontal disease related to the NHANES study design. Periodontal data were derived from random half-mouth examinations measuring two sites per tooth, which underestimates the prevalence of periodontal disease. ${ }^{34}$ This underestimation of periodontal disease in individuals with and without chronic kidney disease results in an underreporting of the true association between chronic kidney disease and periodontal disease. ${ }^{35}$ Although we did not find a significant association between chronic kidney disease and clinical periodontal disease, periodontal pathogen antibody titer levels were associated with chronic kidney disease, similar to those reported in a study of heart disease. Our finding is consistent with Beck et al., ${ }^{10}$ who reported that clinical signs of periodontal disease were not associated with heart disease, but antibody titer levels to Prevotella nigrescens or A. actinomycetemcomitans were associated with heart disease.

Our study has several strengths. First, we focused on the simultaneous assessment of chronic inflammatory burden, including the systemic antibody response to periodontal pathogens and C-reactive protein, in addition to other risk factors for chronic kidney disease. Second, our analysis of the combination of $A$. actinomycetemcomitans and $P$. gingivalis titer suggests that further research is needed to investigate systemic antibody responses to clusters of periodontal pathogens. Third, our multivariable modeling approach begins to address concerns that hostrelated and environmental factors, such as race/ ethnicity, age, diabetes, and smoking, may affect serum antibody levels by simultaneously adjusting for these factors. ${ }^{36}$ Fourth, questionnaire, examination, and laboratory data were collected in an unbiased manner such that the participants were unaware of our study on risk factors/indicators for chronic kidney disease. Fifth, our study population included dentate and edentulous adults, unlike studies discussed previously, which were limited to dentate individuals.

\section{CONCLUSIONS}

Our findings support the conclusion that edentulous adults are more likely to have chronic kidney disease, and those with a high level of systemic antibody response to one of the major periodontal pathogens (A. actinomycetemcomitans) are less likely to have 
chronic kidney disease after controlling for other risk factors. Further research is needed to evaluate the causal inferences regarding the role of periodontal pathogen burden and its contribution to systemic inflammatory burden in longitudinal studies of chronic kidney disease with dentate and edentulous adults. Another potential next step is to consider periodontal therapy as a means to contribute to reducing the chronic inflammatory burden in multifactorial interventions that might include counseling to modify patients' behavior (e.g., smoking cessation counseling, ${ }^{37}$ diet modification, and exercise initiation) and antihypertensive drug therapy ${ }^{3,31,38}$ directed toward reducing the incidence, progression, and complications of chronic kidney disease.

\section{ACKNOWLEDGMENTS}

This research was supported by the National Institutes of Health/National Institute of Dental and Craniofacial Research (grant NIH DE016031-04), Bethesda, Maryland. The authors report no conflicts of interest related to this report.

\section{REFERENCES}

1. Go AS, Chertow GM, Fan D, McCulloch CE, Hsu CY. Chronic kidney disease and the risks of death, cardiovascular events, and hospitalization. N Engl J Med 2004;351:1296-1305.

2. Coresh J, Byrd-Holt D, Astor BC, et al. Chronic kidney disease awareness, prevalence, and trends among U.S. adults, 1999 to 2000. J Am Soc Nephrol 2005; 16 : $180-188$.

3. National Kidney Foundation. K/DOQI clinical practice guidelines for chronic kidney disease: Evaluation, classification, and stratification. Am J Kidney Dis 2002;39 (2 Suppl. 1):S1-S266.

4. Cazzavillan S, Ratanarat R, Segala C, et al. Inflammation and subclinical infection in chronic kidney disease: A molecular approach. Blood Purif 2007;25:69-76.

5. Tonelli M, Pfeffer MA. Kidney disease and cardiovascular risk. Annu Rev Med 2007;58:123-139.

6. Stenvinkel P. New insights on inflammation in chronic kidney disease - genetic and non-genetic factors. Nephrol Ther 2006;2:111-119.

7. Levey AS, Coresh J, Balk E, et al. National Kidney Foundation practice guidelines for chronic kidney disease: Evaluation, classification, and stratification. Ann Intern Med 2003;139:137-147.

8. Kshirsagar AV, Offenbacher S, Moss KL, Barros SP, Beck JD. Antibodies to periodontal organisms are associated with decreased kidney function. The Dental Artherosclerosis Risk in Communities Study. Blood Purif 2007;25:125-132.

9. Fisher MA, Taylor GW, Shelton BJ, et al. Periodontal disease and other non-traditional risk factors for CKD. Am J Kidney Dis 2008;51:45-52.

10. Beck JD, Eke P, Heiss G, et al. Periodontal disease and coronary heart disease - A reappraisal of the exposure. Circulation 2005;112:19-24.

11. Beck JD, Eke P, Lin D, et al. Associations between IgG antibody to oral organisms and carotid intima-medial thickness in community-dwelling adults. Atherosclerosis 2005;183:342-348.

12. Dye BA, Choudhary K, Shea S, Papapanou PN. Serum antibodies to periodontal pathogens and markers of systemic inflammation. J Clin Periodontol 2005;32: 1189-1199.

13. National Center for Health Statistics. National Health and Nutrition Examination Survey III Documentation, Codebook, and Data Files. Available at: http://www.cdc. gov/nchs/about/major/nhanes/nh3data.htm. Accessed November 1, 2007.

14. Coresh J, Astor BC, McQuillan G, et al. Calibration and random variation of the serum creatinine assay as critical elements of using equations to estimate glomerular filtration rate. Am J Kidney Dis 2002;39:920929.

15. Fisher MA, Taylor GW, Tilashalski KR. Smokeless tobacco and severe active periodontal disease, NHANES III. J Dent Res 2005;84:705-710.

16. Phipps KR, Stevens VJ. Relative contribution of caries and periodontal disease in adult tooth loss for an $\mathrm{HMO}$ dental population. J Public Health Dent 1995;55:250252.

17. Desvarieux M, Demmer RT, Rundek T, et al. Relationship between periodontal disease, tooth loss, and carotid artery plaque: The Oral Infections and Vascular Disease Epidemiology Study (INVEST). Stroke 2003; 34:2120-2125.

18. Hujoel PP, Leroux BG, Selipsky H, White BA. Nonsurgical periodontal therapy and tooth loss. A cohort study. J Periodontol 2000;71:736-742.

19. Frohlich ED, Grim C, Labarthe DR, Maxwell MH, Perloff A, Weidman WH. Recommendations for human blood pressure determination by sphygmomanometers. Hypertension 1988;11:209A-222A.

20. American Diabetes Association. Diagnosis and classification of diabetes mellitus. Diabetes Care 2007; 30(Suppl. 1):S42-S47.

21. Pussinen PJ, Tuomisto K, Jousilahti P, Havulinna AS, Sundvall J, Salomaa V. Endotoxemia, immune response to periodontal pathogens, and systemic inflammation associate with incident cardiovascular disease events. Arterioscler Thromb Vasc Biol 2007; 27:1433-1439.

22. Tonetti MS, D'Aiuto F, Nibali L, et al. Treatment of periodontitis and endothelial function. N Engl J Med 2007;356:911-920.

23. Rams TE, Listgarten MA, Slots J. Actinobacillus actinomycetemcomitans and Porphyromonas gingivalis subgingival presence, species-specific serum immunoglobulin G antibody levels, and periodontitis disease recurrence. J Periodontal Res 2006;41:228234.

24. Beck JD, Offenbacher S. Systemic effects of periodontitis: Epidemiology of periodontal disease and cardiovascular disease. J Periodontol 2005;76:20892100.

25. Loos BG. Systemic markers of inflammation in periodontitis. J Periodontol 2005;76:2106-2115.

26. Offenbacher S, Beck JD. A perspective on the potential cardioprotective benefits of periodontal therapy. Am Heart J 2005;149:950-954.

27. Pussinen PJ, Nyyssonen K, Alfthan G, Solonen R, Laukkanen JA, Salonen JT. Serum antibody levels to Actinobacillus actinomycetemcomitans predict the risk for coronary heart disease. Arterioscler Thromb Vasc Biol 2005;25:833-858. 
28. Papapanou PN, Neiderud AM, Disick E, Lalla E, Miller GC, Dahlen G. Longitudinal stability of serum immunoglobulin G responses to periodontal bacteria. J Clin Periodontol 2004;31:985-990.

29. Centers for Disease Control and Prevention (CDC). Prevalence of chronic kidney disease and associated risk factors - United States, 1999-2004. MMWR Morb Mortal Wkly Rep 2007;56:161-165.

30. Bang H, Vupputuri S, Shoham DA, et al. SCreening for Occult REnal Disease (SCORED): A simple prediction model for chronic kidney disease. Arch Intern Med 2007; 167:374-381.

31. Jamerson KA. Preventing chronic kidney disease in special populations. Am J Hypertens 2005;18:106S$111 \mathrm{~S}$.

32. Tonelli M, Sacks F, Pfeffer M, Jhangri GS, Curhan G. Biomarkers of inflammation and progression of chronic kidney disease. Kidney Int 2005;68:237-245.

33. Basile DP. The endothelial cell in ischemic acute kidney injury: Implications for acute and chronic function. Kidney Int 2007;72:151-156.

34. Beck JD, Caplan DJ, Preisser JS, Moss K. Reducing the bias of probing depth and attachment level esti- mates using random partial-mouth recording. Com munity Dent Oral Epidemiol 2006;34:1-10.

35. Hennekens $\mathrm{CH}$, Buring JE. Epidemiology in Medicine. Philadelphia: Lippincott Williams \& Wilkins; 1987:35.

36. Graswinckel JEM, van der Velden U, van Winkelhoff AJ, Hoek FJ, Loos BG. Plasma antibody levels in periodontitis patients and controls. J Clin Periodontol 2004;31:562-568.

37. U.S. Department of Health and Human Services. The health benefits of smoking cessation: A report of the Surgeon General. Rockville, MD: U.S. Department of Health and Human Services, CDC; 1990.

38. Rahman M, Pressel S, Davis BR, et al. Renal outcomes in high-risk hypertensive patients treated with an angiotensin-converting enzyme inhibitor or a calcium channel blocker vs a diuretic. Arch Intern Med 2005;165:936-946.

Correspondence: Dr. Monica A. Fisher, Case Western Reserve University, 10900 Euclid Ave., Cleveland, OH 44106-4905. Fax: 216/368-0145; e-mail: monica.fisher@ case.edu.

Submitted November 1, 2007; accepted for publication February 20, 2008. 